\title{
The Role of Certifying Boards in Improving Health: The Example of the American Board of Pediatrics
}

\author{
Carole Lannon, MD, MPH and David G. Nichols, MD, MBA
}

The quality of care for children and adults in the United States is variable and often suboptimal. Approaches that improve the systems of care for entire patient populations are needed. The certifying medical boards can contribute to driving change by ensuring that improving care and outcomes for patients and families is the priority. The American Board of Pediatrics has catalyzed collaborative improvement networks, resulting in improved health outcomes for children, fostered partnerships with patients and families, and brought together key stakeholders to advocate for network improvement efforts for sickle cell disease as one action to address health disparities. Similar concerted efforts by certifying boards in collaboration with physicians and patients can improve the quality of care and lead to better patient outcomes. ( $\mathrm{J}$ Am Board Fam Med 2020;33:S36-S41.)

Keywords: Certification, Pediatrics, Physicians, Quality of Health Care

\section{Introduction}

The quality of care for children and adults in the United States is variable and often suboptimal. ${ }^{1,2}$ Approaches that improve the systems of care for entire patient populations are needed. The certifying medical boards can contribute to driving change by ensuring that improving care and outcomes for patients and families is the priority. Several examples from the American Board of Pediatrics' (ABP's) quality journey over the last 2 decades highlight how boards can catalyze improvement efforts and drive results.

\section{The History of Pediatric National Improvement Networks}

In 2002, the ABP chartered a workgroup of quality improvement (QI) design experts and representatives

This article was externally peer reviewed.

Submitted 24 March 2020; revised 18 June 2020; accepted 22 June 2020.

From the Learning Networks Program, James M. Anderson Center for Health Systems Excellence, Cincinnati Children's Hospital Medical Center, University of Cincinnati, Cincinnati, OH (CL); American Board of Pediatrics, Chapel Hill, NC (DGN, CL).

Funding: Dr. Lannon serves in a consulting role to the American Board of Pediatrics as Senior Quality Advisor.

Conflict of interest: Dr. Lannon is an inventor of technology to support Learning Health System Networks that has been licensed to Hive Networks by Cincinnati Children's.

Corresponding author: Carole Lannon, MD, MPH, Learning Networks Program, The James M. Anderson Center for Health Systems Excellence, Cincinnati Children's Hospital Medical Center, University of from all pediatric subspecialties. This workgroup developed a framework for the "performance in practice" component of the nascent maintenance of certification (MOC) requirements with the explicit goal of improving child health outcomes rather than simply documenting compliance with certification standards. $^{3}$ At that time, most QI efforts were short-term projects focused on improving care processes (e.g., providing an asthma action plan during clinic visits). Time-bounded, narrowly focused projects are important components of improving quality, but improving outcomes for populations of children required a QI network model. The improvement network model had the following essential elements:

- A specific aim to improve care.

- A national, multicenter, prospective approach to QI.

- Reduction of unnecessary variation by identifying, adopting, and testing best practices.

- Shared, valid, high-quality real-time data.

- Infrastructure support to apply improvement science.

- Public sharing of outcomes to spread best practices.

In 2007, the ABP provided seed funding for an improvement network in pediatric gastroenterology, later known as the ImproveCareNow (ICN) network,

Cincinnati, 3333 Burnet Avenue, MLC 7014, Cincinnati, OH 45229-3026 (E-mail: Carole.Lannon@cchmc.org). 
Figure 1. Illustrates the increase in clinical remission for patients with inflammatory bowel disease (IBD) at ImproveCareNow Network centers between 2007 and 2019. The graph uses data from the ImproveCareNow registry for care centers that have enrolled more than $75 \%$ of their IBD patient cohort.

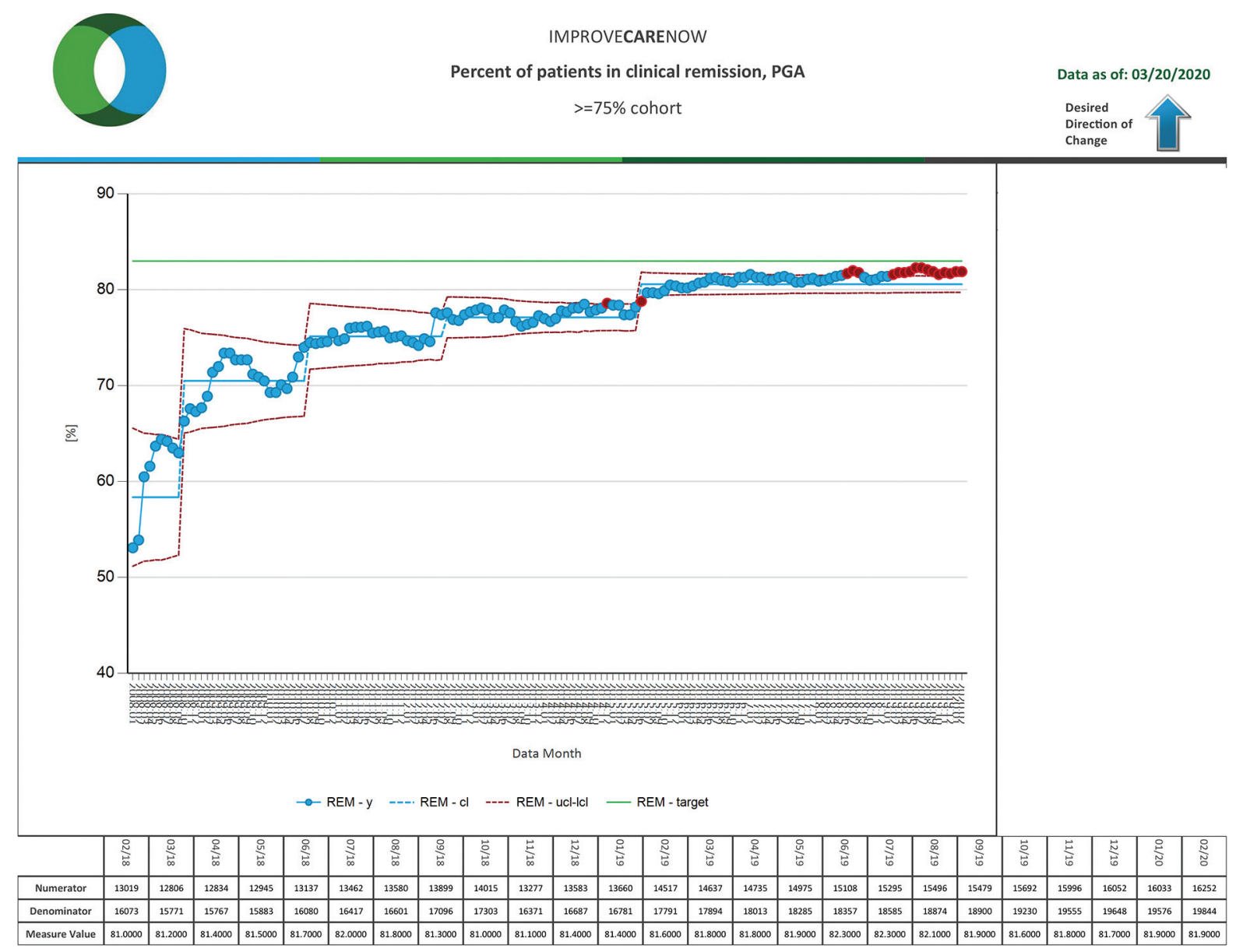

which focuses on improving care and outcomes in pediatric inflammatory bowel disease. ${ }^{4}$ The original participating centers standardized diagnostic assessment and treatment algorithms. Now, with more than 109 participating centers, ICN has improved the remission rate of children and adolescents with inflammatory bowel disease from $55 \%$ to $82 \%$ without the use of new medications (Figure 1). ${ }^{5}$ In addition to improved health outcomes, ${ }^{6,7}$ this network has documented multiple successes in care processes, ${ }^{8,9}$ patient engagement and coproduction, ${ }^{10}$ and the development of digital tools to improve clinical processes and data collection. ${ }^{11}$

Several other networks have replicated the model successfully, ${ }^{12}$ including Solutions for Patient Safety (SPS), with $135+$ participating children's hospitals, which since 2012 has protected 12,722 children from serious harm (e.g., hospital-acquired conditions, unplanned extubations, and serious safety events) and has led to an estimated savings of nearly $\$ 175$ million. ${ }^{13-15}$ The 65 cardiology centers in the National Pediatric Cardiology Quality Improvement Collaborative (NPCQIC) have collectively decreased mortality by more than $40 \%$ among infants with hypoplastic left heart disease. ${ }^{16}$ The Ohio Perinatal Quality Collaborative (OPQC) has improved perinatal outcomes in several domains: reduced early elective deliveries by $75 \%{ }^{17,18}$ (Figure 2), reduced late onset sepsis in preterm infants, ${ }^{19}$ reduced length of hospitalization for infants with neonatal abstinence syndrome, ${ }^{20}$ and reduced births of $<32$ weeks gestation by $6.6 \%$ through a statewide progesterone program. ${ }^{21}$ OPQC was selected as a mentor network for the development of the Centers for Disease Control and Prevention's National Network of Perinatal Quality Collaboratives. ${ }^{22}$ These examples illustrate the success of the network model for many different populations, including inpatient safety, chronic conditions, rare diseases, and newborns. 
Figure 2. Illustrates the decline in induced births between 37 and 38 weeks of gestation without medical indication, beginning in 2008 with the initiation of the Ohio Perinatal Quality Collaborative Early Elective Delivery project. The graph uses State of Ohio vital statistics data.

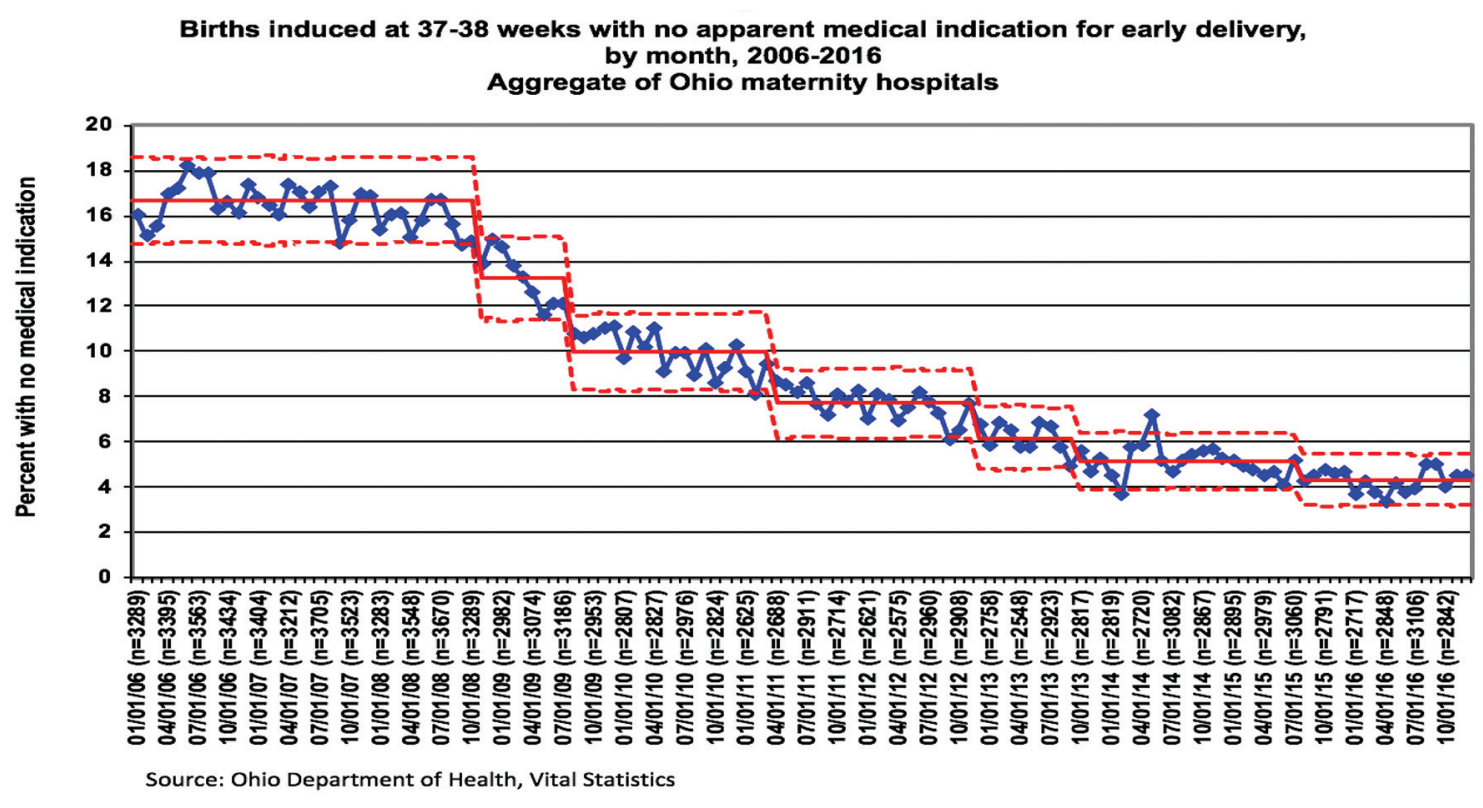

\section{Network Methodology}

Network funding comes from various sources. The chronic disease and safety networks are funded by site participation fees, philanthropic support, supplementary grants for research and innovation, and sponsorship of specific activities (e.g., network conferences). The perinatal quality collaboratives are usually supported by government grants.

Improvement networks use QI methods to promote ongoing learning within and across network sites. Networks have adapted the Breakthrough Series model $^{23}$ by using face-to-face learning sessions, testing during action periods, and regular performance feedback so that quality efforts endure over years.

User-centered design and improvement science principles underpin network development. ${ }^{12,24} \mathrm{Co}-$ production of the improvement program by patients, families, clinicians, and researchers is the critical principle of user-centered design. These stakeholders identify priorities, aims, outcome metrics, and practical approaches to test and implement improvement strategies collaboratively.

Initial network improvement efforts in pediatrics tended to be project focused, time-bounded, and pediatrician centric and emphasized changing clinician behavior. Over time, the networks recognized that improving outcomes for populations of children required addressing the systems of care and engaging all stakeholders (e.g., patients, families, clinicians, and researchers). The resulting culture of collaboration and trust is foundational to an improvement community that uses data to facilitate learning and sharing of best practices. With the inclusion of research into QI networks, the model is now known as the Learning Network model. ${ }^{12}$ This evolution was consistent with the development of the Institute of Medicine's Learning Healthcare System model. ${ }^{25}$

\section{QI and Learning Networks in Primary Care}

The ABP has also actively promoted collaborative improvement programs in pediatric primary care. These include the American Academy of Pediatrics (AAP) national collaboratives on various topics, such as immunizations, asthma, developmental screening, and obesity prevention and treatment. ${ }^{26,27}$ Examples of successful AAP state chapter improvement efforts include the Alabama Child Health Improvement Alliance, ${ }^{28}$ the Ohio chapter, ${ }^{29,30}$ and the Vermont Child Health Improvement Program. ${ }^{31}$ In addition 
to the AAP, the National Improvement Partnership Network (NIPN) is the other major pediatric primary care network. In over 20 states, NIPN has developed durable state or regional collaborations to advance quality and to improve health care for children. ${ }^{32,33}$

\section{Patient and Families as Network Partners}

An important advance in the network improvement model was recognizing the necessity of an equal partnership with patients and families. Systems of care do not change effectively without engaging all the stakeholders. Thus, the networks changed from having patients and families as advisors to working with them as true partners. Outcomes of importance to patients and families are viewed equitably with those of importance to clinicians and researchers. For example, with parental input, the Autism Learning Health Network has prioritized addressing disruptive behaviors and quality of life for affected children. In the ICN network, young adult patients with ostomies collaborated with clinicians and published "A Guide to Gutsy Living" for teen peers. ${ }^{34}$ Parental input in NPCQIC made optimizing nutrition a key area of focus so that infants with complex congenital heart disease would be able to eat cake on their first birthday. Parents also asked pediatric cardiologists in NPCQIC to develop simple explanations of important findings from medical publications. These 1-page summaries for lay readers known as "Research Explained" 35 live on both the network and parent organization web sites. Any research project using the network's registry data must have a lay summary.

\section{The ABP Partnership with Patient and Families}

At an ABP-sponsored "Partnering with Patients and Families" conference, parents identified a significant gap in emotional health support for children with chronic conditions and their families. In follow-up, the ABP launched the "Roadmap Project" to optimize the resilience and emotional health of children with chronic conditions and their families. ${ }^{36}$ As part of this initiative, pediatricians, child psychologists, young adult patients, and parents of children with chronic conditions identify practical strategies and develop useful tools to help clinicians build competence in behavioral and mental health care. A pilot improvement collaborative with teams from 9 children's hospitals launched in January 2020 to test various Roadmap strategies.

At another ABP Patient and Family conference, a mother of twins with sickle cell disease (SCD) asked the ABP CEO, "why isn't there a Learning Network for SCD?" Data indicate that disparities in the care and outcomes of Black children with SCD include suboptimal antibiotic prophylaxis, pneumococcal vaccination, hydroxyurea use, transcranial doppler imaging, and transition of care planning from adolescence to adulthood. ${ }^{37,38}$ In response, the ABP has partnered with the American Society of Hematology, federal agencies, and SCD patient advocacy groups, to consider the development of an SCD Learning Network.

Developing a Learning Network for SCD is one effort to improve outcomes for a vulnerable and often underserved population. This can be part of an aggressive strategy to eliminate racial and ethnic disparities in health care. ${ }^{39-42}$

\section{The Role of the Certifying Board in Catalyzing Improvement Networks}

The ABP has used multiple strategies to achieve its "North Star" of improving of health outcomes for children, adolescents, and young adults. From the beginning, ABP leadership has championed the network model's promise to improve health outcomes for children. In addition, a pediatrician expert in the design and implementation of QI networks (CL) has served as Senior Quality Advisor to the ABP.

Stakeholder convening and engagement has been another strategy. The ABP hosted meetings of subspecialty leaders and relevant professional organizations to share the network potential and early successes. These meetings spawned the networks for pediatric cardiology, rheumatology, and patient safety. The ABP subboard chairs worked with their professional organizations to publicize opportunities for network participation. Local engagement rose by making it possible for every pediatrician in the networks to earn MOC points.

Dissemination of the impact of Learning Networks has been a third strategy. A 2013, ABP meeting of patients, parents, clinicians, governmental leaders, payers, and professional organizations led to a supplement in the journal Pediatrics, namely, "Pediatric Collaborative Improvement Networks." ${ }^{3}$ The ABP Annual Report, mailed to all ABP diplomates, highlighted collaborative improvement efforts in primary 
and subspecialty care. ${ }^{43}$ In addition, the $\mathrm{ABP}$ gives the Paul V. Miles Fellowship award annually to a pediatrician who has demonstrated excellence in improving the quality of care for children. ${ }^{44}$

The ABP process for providing Part 4 MOC credit for participation in collaborative improvement efforts is designed to foster clinician engagement. Network leaders submit the applications for improvement activities directly to the $\mathrm{ABP}$ or an approved Portfolio Sponsor organization. Many of the AAP state chapters and regional improvement partnerships serve as Portfolio Sponsor organizations. As part of the application, collaborative leaders define the level of participation required for a physician to be eligible to receive MOC Part 4 credit. In general, meaningful participation is defined as (1) implementing the project's interventions, (2) reviewing the project's measurement data, and (3) attending in-person or virtual team meetings. Verification of a physician's participation occurs at the local level, and the project leaders award the Part 4 points on behalf of the ABP. The aim is for the ABP to support local QI and ensure physicians get credit for the meaningful improvement work they are doing within the context of their practice.

\section{Conclusions}

In summary, the ABP has catalyzed collaborative improvement networks, resulting in improved health outcomes for children; fostered partnerships with patients and families; and brought together key stakeholders to advocate for network improvement efforts for sickle cell disease as one action to address health disparities. Similar concerted efforts by certifying boards in collaboration with physicians and patients can improve the quality of care and lead to better patient outcomes.

To see this article online, please go to: http://jabfm.org/content/ 33/Supplement/S36.full.

\section{References}

1. Levine DM, Linder JA, Landon BE. The quality of outpatient care delivered to adults in the United States, 2002 to 2013. JAMA Intern Med 2016;176:1778-90.

2. Mangione-Smith R, DeCristofaro AH, Setodji CM, et al. The quality of ambulatory care delivered to children in the United States. N Engl J Med 2007;357:1515-23.

3. Lannon CM, Peterson LE. Pediatric collaborative improvement networks: background and overview. Pediatrics 2013;131:S189-S195.
4. Lannon CM, Peterson LE. Pediatric collaborative networks for quality improvement and research. Acad Pediatr 2013;13:S69-S74.

5. ImproveCareNow Purpose and Success. Available from: https://www.improvecarenow.org/purposesuccess. Accessed March 20, 2020.

6. Crandall WV, Margolis PA, Kappelman MD, et al. ImproveCareNow Collaborative. Improved outcomes in a quality improvement collaborative for pediatric inflammatory bowel disease. Pediatrics 2012;129: e1030-e1041.

7. Savarino JR, Kaplan JL, Winter HS, Moran CJ, Israel EJ. Improving clinical remission rates in pediatric inflammatory bowel disease with previsit planning. BMJ Qual Improv Rep 2016;5:1-5.

8. Dykes D, Williams E, Margolis P, et al. Improving pediatric inflammatory bowel disease (IBD) followup. BMJ Qual Improv Rep 2016;5:u208961.

9. Prendaj E, Thomas S, Tomer G. Population management: a tool to improve timely care in pediatric and young adult patients with inflammatory bowel disease. Gastroenterol Res Pract 2019;2019:1-7.

10. Seid M, Margolis PA, Opipari-Arrigan L. Engagement, peer production, and the learning healthcare system. JAMA Pediatr 2014;168:201-2.

11. Marsolo K, Margolis PA, Forrest CB, Colletti RB, Hutton JJ. A digital architecture for a network-based learning health system: integrating chronic care management, quality improvement, and research. eGEMs 2015;3:16.

12. Britto MT, Fuller SC, Kaplan HC, et al. Using a network organisational architecture to support the development of Learning Healthcare Systems. BMJ Qual Saf 2018;27:937-46.

13. Solutions for Patient Safety. Our Results. Available from: https://www.solutionsforpatientsafety.org/ourresults/. Accessed March 20, 2020.

14. Lyren A, Brilli RJ, Zieker K, Marino M, Muething S, Sharek PJ. Children's hospitals' solutions for patient safety collaborative impact on hospitalacquired harm. Pediatrics 2017;140:e20163494.

15. Klugman D, Melton K, Maynord PO, et al. Assessment of an unplanned extubation bundle to reduce unplanned extubations in critically ill neonates, infants, and children. JAMA Pediatr 2020;174:e200268.

16. Anderson JB, Beekman RH, III, Kugler JD, et al. National Pediatric Cardiology Quality Improvement Collaborative. Improvement in interstage survival in a National Pediatric Cardiology Learning Network. Circ Cardiovasc Qual Outcomes 2015;8:428-36.

17. Kaplan HC, Mangeot C, Sherman SN, et al. Dissemination of a quality improvement intervention to reduce early term elective deliveries and improve birth registry accuracy at scale in Ohio. Obstet Gynecol 2018;131:688-95.

18. The Ohio Perinatal Quality Collaborative Writing Committee. A statewide initiative to reduce 
inappropriate scheduled births at 360/7-386/7 weeks' gestation. Am J Obstet Gynecol 2010;202:243.e1243.e8.

19. Kaplan HC, Lannon C, Walsh MC, Donovan EF, for the Ohio Perinatal Quality Collaborative. Donovan EF and for the Ohio Perinatal Quality Collaborative. Ohio statewide quality-improvement collaborative to reduce late-onset sepsis in preterm infants. Pediatrics 2011;127:427-35.

20. Walsh MC, Crowley M, Wexelblatt S, et al. Ohio Perinatal Quality Collaborative improves care of neonatal narcotic abstinence syndrome. Pediatrics 2018;141:e20170900.

21. Iams JD, Applegate MS, Marcotte MP, et al. A statewide progestogen promotion program in Ohio. Obstet Gynecol 2017;129:337-46.

22. National Network of Perinatal Quality Collaboratives. Available from: https://www.cdc.gov/ reproductivehealth/maternalinfanthealth/nnpqc.htm. Accessed March 20, 2020.

23. The Breakthrough Series. IHI's collaborative model for achieving breakthrough improvement. IHI Innovation Series white paper. Boston (MA): Institute for Healthcare Improvement; 2003.

24. Kappelman MD, Crandall WV, Colletti RB, et al. ImproveCareNow: the development of a pediatric IBD improvement network. Inflamm Bowel Dis 2011;17:450-7.

25. Institute of Medicine Roundtable on Evidence-Based Medicine, Olsen LA, Aisner D, McGinnis JM, eds. The learning healthcare system: workshop summary. Washington, DC: National Academies Press; 2007.

26. Dolins JC, Powell J, Wise E, et al. Improving asthma care by building statewide quality improvement infrastructure. Pediatrics 2017;140:e20161612.

27. Frost HM, Andersen LM, Fleming-Dutra KE, Norlin C, Czaja CA. Sustaining outpatient antimicrobial stewardship: do we need to think further outside the box?. Infect Control Hosp Epidemiol 2020;41:382-4.

28. Alabama Child Health Improvement Alliance. Available from: https://www.achia.org/. Accessed May 28, 2020.

29. American Academy of Pediatrics Ohio Chapter. Building mental wellness program. Available from: http://ohioaap.org/projects/building-mental-wellness/. Accessed May 27, 2020.

30. Weidenbenner AE, Sternstein AR, Bakies K, Murray $\mathrm{R}$, Scarpitti H. An ounce of prevention is worth a pound a physician's toolkit to prevent childhood obesity. J Acad Nutr Diet 2008;108:9: Supplement A53.

31. Weinberger SJ, Cowan KJ, Robinson KJ, et al. A primary care learning collaborative to improve office systems and clinical management of pediatric asthma. J Asthma 2019;14:1-10.
32. National Improvement Partnership Network (NIPN). Available from: http://www.med.uvm.edu/nipn/home. Accessed May 27, 2020.

33. Shaw JS, Norlin C, Gillespie RJ, Weissman M, McGrath J. The national improvement partnership network: state-based partnerships that improve primary care quality. Acad Pediatr 2013;13:S84-S94.

34. David JG, Jofriet A, Seid M, Margolis PA, for the ImproveCareNow Pediatric IBD Learning Health System. "A guide to gutsy living": patient-driven development of a pediatric ostomy toolkit. Pediatrics 2018;141:e20172789.

35. National Pediatric Cardiology Quality Improvement Collaborative. Research Explained. Available from: https://npcqic.org/research-explained. Accessed March 20, 2020 .

36. American Board of Pediatrics. Roadmap to resilience, emotional, and mental health. Available from: https:// www.abp.org/foundation/roadmap. Accessed March 20, 2020.

37. Reeves SL, Tribble AC, Madden B, Freed GL, Dombkowski KJ. Antibiotic prophylaxis for children with sickle cell anemia. Pediatrics 2018;141: e20172182.

38. Reeves SL, Madden B, Freed GL, Dombkowski KJ. Transcranial doppler screening among children and adolescents with sickle cell anemia. JAMA Pediatr 2016;170:550-6.

39. Alegria M, Vallas M, Pumariega AJ. Racial and ethnic disparities in pediatric mental health. Child Adolesc Psychiatr Clin N Am 2010;19: 759-74.

40. Alegría M, Alvarez K, Ishikawa RZ, DiMarzio K, McPeck S. Removing obstacles to eliminating racial and ethnic disparities in behavioral health care. Health Aff (Millwood) 2016;35:991-9.

41. Cheng TL, Emmanuel MA, Levy DJ, Jenkins RR. Child health disparities: what can a clinician do? Pediatrics 2015;136:961-8.

42. Trent M, Dooley DG, Dougé J, Section on Adolescent Health; Council on Community Pediatrics; Committee on Adolescence. The impact of racism on child and adolescent health. Pediatrics 2019;144:e20191765.

43. American Board of Pediatrics. American Board of Pediatrics Annual Report. 2017. Available from: https://www.abp.org/sites/abp/files/pdf/2017_abp_ annual_report.pdf. Accessed May 27, 2020.

44. American Board of Pediatrics. Nominations for the 2020 Paul V. Miles Fellowship. Available from: https://www.abp.org/news/nominations-2020-paulv-miles-fellowship-accepted-now. Accessed May 27, 2020. 